\title{
A Stylistic Analysis of To Room Nineteen
}

\author{
Yu Hua ${ }^{*}$, Guo Jian \\ Department of Foreign Languages, University of Chinese Academy of Sciences, China
}

Copyright (C) 2015 Horizon Research Publishing All rights reserved.

\begin{abstract}
Doris Lessing was a British woman writer who won the Nobel Prize for literature in 2007. To Room Nineteen is the representative short novel that features her writing style. In this short novel, Doris Lessing narrates with exquisite style and literary languages an inexplicable tragic story of a female character Susan Rowling, a middle-aged full-time housewife from an affluent middle-class family. Many critics claim that Susan's suicide is a reflection of women's struggle in a patriarchal society, and Susan herself is the victim in the male-dominated society and culture. The purpose of this paper is to have a stylistic analysis of To Room Nineteen, and therefore to substantiate the above-mentioned literature critics' opinions on it. Through careful reading, studying and analyzing of this short novel's lexical features, we have drawn two conclusions: 1. a careful stylistic analysis on lexical features could help readers understand and evaluate a literary works' theme; here, in this short novel, the stylistic analysis has provided evidences to illustrate why the culprit of Susan's suicide is the patriarchal society, rather than the so-called "failure in intelligence"; 2. our stylistic analysis suggests that the influence of male-dominated society and culture is universal, broad, and deep, no matter whether the impacted subjects (especially females) are well-educated or not, intelligent or not, affluent or not. Susan in To Room Nineteen, a well-educated intelligent woman from an affluent family, could be considered as an epitome of millions of other women who, like Susan, suffer from the patriarchal control and who struggle to fight against it with their lives.
\end{abstract}

Keywords Lessing, To Room Nineteen, Stylistic Analysis, Lexical Features

\section{Introduction}

Doris May Lessing (1919-2013) was a prolific British writer, and she was best remembered as a novelist, poet and short story writer. When she was awarded the 2007 Nobel Prize in Literature, the Swedish Academy described her as "that epicist of the female experience, who with skepticism, fire and visionary power has subjected a divided civilization to scrutiny",[1].
As a female Nobel laureate herself, notably, Doris Lessing did not like being attached with a feminist label. However, topics or stories on female experience have always been the highlighted focuses and concerns in her works, and she had successfully created many unforgettable female images in English literature, including Mary Turner in "The Grass Is Singing" and Anna Wulf in "The Golden Notebook". In this paper, we will study a tragic female image, Susan Rawlings in "To Room Nineteen".

"To Room Nineteen", a short story written and first published in "A Man and Two Women" in 1963, later published in "To Room Nineteen: Collected Stories, Vol. 1" in 1978, helps Lessing achieve her reputation as a known short story writer. "To Room Nineteen" starts with the Rawlings' happy marriage and family. After pregnant with the first baby, Susan Rawlings, a well-educated, intelligent woman, quitted her job to be a full-time housewife. Thereafter, in her life, to take care of four kids, her husband and their big gardened-house had been the top priorities. And all of these were considered to be natural and sensible for any intelligent human being. However, Matthew's one-night affair with a young girl broke this happy scene and eventually destroyed it. Susan recognized that she had lost her self, and always felt she was threatened. Again and again, through different ways, Susan tried to escape from her family, from the control of her husband. In Room Nineteen of a shabby hotel, she thought she could gain her freedom and peace. Unfortunately, Matthew found this hidden place. Unable to face her husband and family, Susan committed suicide in Room Nineteen. ${ }^{[2]}$

Previous literature studies on "To Room Nineteen" have revealed that the male-dominated society is the underlying root of Susan's failure and death. Many critics claim that Susan's suicide is a reflection of women's struggle in a patriarchal society, and Susan herself is the victim in the male-dominated society and culture. ${ }^{[3][4][5]}$

This paper tries to explore whether their analysis and conclusion are understandable by providing a stylistic analysis, particular on lexical features, according to linguistic and stylistic categories proposed by Leech and Short (1981). ${ }^{[6][7]}$

\section{Stylistic Analysis on Lexical Features}


Table 1. The relationship between nouns used to refer to "the enemy" and Susan's mental condition

\begin{tabular}{|lll|}
\hline Nouns referring to what Susan was afraid of & & Susan's mental condition \\
The enemy & $\rightarrow \rightarrow \rightarrow$ & She was feeling lost, trying to avoid her home. \\
The demon & $\rightarrow \rightarrow \rightarrow$ & She was very nervous and frightened. \\
A youngish man & $\rightarrow \rightarrow \rightarrow$ & She was suffering a mental breakdown. \\
\hline
\end{tabular}

\subsection{Nouns}

After Matthew, Susan's husband, revealed his one-night affair with a young girl, Susan started to avoid their house and their garden, where she thought resided something dangerous. Different nouns are employed to refer to something Susan was scared of:

... and she returned to the house determined to face the enemy wherever he was, in the house, or the garden or-where? (Para. 47)

She waited for the demon to appear and claim her, but he did not. (Para. 50)

She imagined him, or it, as a youngish man, or perhaps $\underline{\boldsymbol{a}}$ middle-aged man pretending to be young. (Para. 74)

Through the close reading of the underlined nouns, readers could understand that what Susan was afraid of is a demon, which possesses the following quality: male, young, strong, and powerful.

The image of "the enemy" is becoming more vividly illustrated when other nouns, such as "the demon", "a youngish man" and "a middle-aged man" are used. The sequence of these nouns - the enemy, the demon, and then a youngish man or a middle-aged man - should not be ignored. They could tell the readers that the fear in Susan's mind was growing and was becoming increasingly evident, as Susan herself became increasingly nervous and even would suffer a mental breakdown at any moment, which foretells the tragic ending of the story (See Table 1). Whatever the enemy is, "the demon" or "a youngish man", it is a symbol itself, representing the threat and the danger caused by the patriarchal society. The selection of lexical words, such as nouns, can reveal character's mental style. ${ }^{[8][9]}$

\subsection{Adjectives}

In this short story, Susan is obviously the main character, while her husband Matthew is not. However, the writer had used different strategies to describe how Susan and Matthew looked like. As is seen in Table 2, Lessing had used more adjectives to describe Matthew. The image of Matthew appears to be more vivid and more specific than that of Susan. Some of adjectives, such as "manly", "big", and "solid", not only indicate Matthew's physical appearance, but also signify the strength and power of patriarchal society. In contrast, it is hard for readers to imagine what Susan exactly looks like. After close reading of this story, we find out only one adjective ("goodlooking", see Table 2) for Susan's appearance, which conveys a quite unclear picture of what our main character looked like. The vagueness of her face and her physical appearance indicates that Susan represents other females in this man-controlled society and she is just one of the average women in such a world. What she looks like is not important, but what she represents is much more meaningful. The more unclear her face is, the more representative she is, and the more sympathetic readers will feel for women and their conditions.

Table 2. Adjectives used to describe Matthew's and Susan's physical appearance

\begin{tabular}{|l|c|}
\hline $\begin{array}{c}\text { Adjectives used to describe } \\
\text { Matthew's physical appearance }\end{array}$ & $\begin{array}{c}\text { Adjectives used to describe } \\
\text { Susan's physical appearance }\end{array}$ \\
\hline $\begin{array}{l}\text { handsome, blond, attractive, } \\
\text { manly, sullen, big, solid, clear, } \\
\text { blue-eyed, }\end{array}$ & goodlooking \\
$\begin{array}{l}\text { intelligent, where } \\
\text { incredulous, pinkish, white }\end{array}$ & \\
\hline
\end{tabular}

In this story, Susan's psychological change took place after Matthew told her his affair with another girl. Susan persuaded herself to forgive Matthew, but actually this always a Gordian knot for her, striking her in a way that such an intelligent and sensible woman as she was could not perceive. Things started to change. Before Matthew's revelation, everything is perfect for Susan, and her life, marriage, and family are symbols for happiness. Now, their beautiful garden house became a suffocating place, forfeiting her freedom. The river outside their house changed in Susan's eyes as well. The river used to be "attractive". Now, it was "wild", "brown", and "slow-moving" (See Table 3). These adjectives, especially the color of "brown", suggest Susan's mental condition. It is the externalization of Susan's psychological conditions. ${ }^{[10]}$ Susan longed for her own room, her own space, and her freedom. The beautiful garden house, along with its outside surroundings, became yokes and chains for her, since all of these were financially supported by Matthew. They were dark and stifling, full of pressure.

Table 3. Adjectives used to describe the river before and after Matthew's revelation

\begin{tabular}{|c|c|}
\hline $\begin{array}{c}\text { Adjectives used to describe the } \\
\text { river before Matthew's } \\
\text { revelation }\end{array}$ & $\begin{array}{c}\text { Adjectives used to describe the } \\
\text { river after Matthew's } \\
\text { revelation }\end{array}$ \\
\hline attractive & $\begin{array}{c}\text { wild, sullied, brown, } \\
\text { slow-moving }\end{array}$ \\
\hline
\end{tabular}

Colors of objects may help writers as well as readers create visual images. In "To Room Nineteen", color-related Adjectives have been used to depict the demon in Susan's imagination. For example:

And he had a reddish complexion, and ginger hair. That was he-a gingery, energetic man, and he wore a reddish hairy jacket, unpleasant to the touch. (Para. 74)

... his ugly yellow boots with a leafy twig (Para. 92) 
Those adjectives (including reddish, ginger, gingery, and yellow) show a bright but frightening combination of colors. Together they form a picture of warming color, but rather not the warming colors in a pleasant way. Instead, they are the warning colors in virulent animals, like some insects or snakes aposematically colored. Through these colors, readers could perceive Susan's great fear, could understand how eager Susan wants to escape from the demon, which signifies the male's control and power over female.

\subsection{Personal Pronouns}

Before Matthew's revelation of his one-night affair, the most frequently used personal pronoun is the pronoun of third person plural, including "they", "them", "their", and "themselves". For example, in the Paragraph 2-4, the pronoun "they" has been used for 12 times. These pronouns, like "they", "them", "their" and "themselves", are all related to the Rawlings, who will be introduced in the following part of the short story. On the one hand, the high frequency of these pronouns has created a picture of a happy couple, who matched each other, perfectly. Matthew and Susan are a unit, similar in personalities, in experiences, and in sensible intelligence. The frequent use of these pronouns creates a picture of ideal husband and wife. On the other hand, the use of "they" has connected these three paragraphs to the mention of Matthew and Susan in $5^{\text {th }}$ paragraph, it holds paragraph 2, 3 and 4 together into one piece: the happy beginning of the Rawlings' marriage.

However, after Matthew's revelation of his one-night affair, the third person plural pronouns have been used less and less. Instead, the third person singular feminine pronoun, i.e. "she", referring to Susan, seems to be the pronoun that is used most. Obviously, Matthew's affair pushed Susan into a hell. Susan's suffering is what this short story has mainly depicted. The high frequent use of "she" and the much less used pronoun "he" by contrast indicates Susan had split from "they", from Matthew, and Susan was eager to get out of him to achieve her own freedom. In addition, the high frequency of the pronoun "she" suggests that Susan was the main character of this short story, the suffered subject of the male-dominated society. The pronoun "she" is also much more used than the name "Susan". "She" stands for any woman in this male-dominated society, while "Susan" is a particular female individual only.

Moreover, as the writer used the pronoun "he" to refer "the enemy" or "the demon", it can be perceived by readers that something threatening and dangerous in Susan's heart is related to male's property, since the pronouns here are "he" and "him" - the masculine pronouns of the third person, instead of "she" or "her". This particular choice of personal pronouns reveals the pressure and threats imposed on Susan by the male-dominated society.

\section{Conclusions}

Through careful reading, studying and analyzing of this short story's lexical features, we have drawn two conclusions: 1. a careful stylistic analysis on lexical features could help readers understand and evaluate a literary works' theme; here, in this short novel, the stylistic analysis has provided evidences to illustrate why the culprit of Susan's suicide is the patriarchal society, rather than the so-called "failure in intelligence"; 2 . our stylistic analysis on lexical features suggests that the influence of male-dominated society and culture is universal, broad, and deep, no matter whether the impacted subjects (especially females), are well-educated or not, intelligent or not, affluent or not. Susan in To Room Nineteen could be considered as an epitome of millions of other women who, like Susan, suffer from the patriarchal control and who struggle to fight against it with their lives.

\section{REFERENCES}

[1] http://en.wikipedia.org/wiki/Doris_Lessing, accessed to on Feb. 11, 2015.

[2] Lessing D. Stories [M]. New York: Vintage Books. 1980: 396-428

[3] 何忠宝, 苏珊悲剧原因探究--析《到十九号房》 [J], 文学 界(2011: 1).

[4] 雷娟, 《到十九号房间》主人公的生存困境解读 $[\mathrm{J}]$, 安徽 工业大学学报(社会科学版)(2012: 3).

[5] 程坤, 从二元对立来解读《到十九号房间》中的女权思想 [J], 牡丹江教育学院学报(2012: 1).

[6] Leech, G. \& Short, M. (1981). Style in Fiction: A Linguistic Introduction to English Fictional Prose [M]. London: Longman.

[7] Michael Toolan, Language in Literature: An Introduction to Stylistics [M], 外语教学与研究出版社, 北京: 2008 .

[8] 董启明, 新编英语文体学教程 $[\mathrm{M}]$, 外语教学与研究出 版社，北京：2009.

[9] 曲卫国, 话语文体学导论: 文本分析方法[M], 复旦大学 出版社, 上海：2009.

[10] 黎林. 《到十九号房间》的意象研究 [J], 天津外国语学院 学报. 2008,(5): 58-64. 